\title{
A MUSICIAN AT WILL OF HIS HEART (ON THE 100TH ANNIVERSARY OF THE FAMOUS TATAR COMPOSER ENVER BAKIROV)
}

Nelia Khabibullovna Nurgayanova, Kazan Federal University, 18 Kremlyovskaya Str., Kazan, 420008, Russian Federation, G. Ibragimov Institute of Language, Literature and Art,

Tatarstan Academy of Sciences, 12 K. Marx Str., Kazan, 420111, Russian Federation, naila-n@mail.ru.

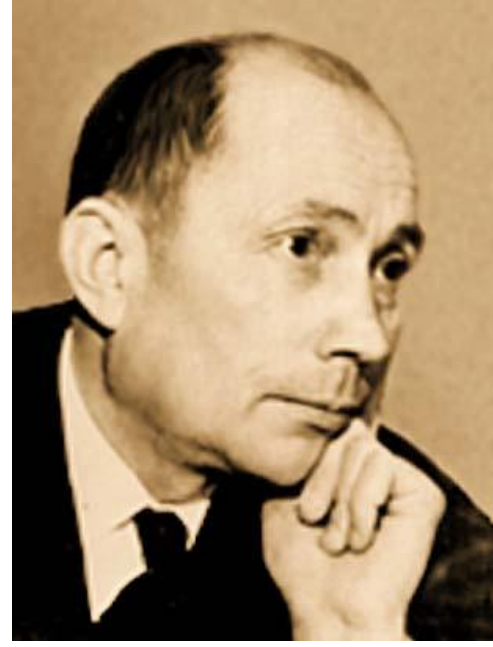

Enver Zakirovich Bakirov (July 7, 1920, Kazan - August 10, 2001, Kazan) was a Soviet and Russian composer, Honored Art Worker of the Tatar ASSR (1969), the RSFSR (1981), a laureate of the State Prize of the Tatar ASSR named after Gabdulla Tukay (1973), People's Artist of the Republic of Tatarstan (1993). In 1940, he graduated from the Kazan Musical College. In 1940-1946, Bakirov served in the armed forces and retired with the rank of guard lieutenant. In 1942, he graduated from the Ulyanovsk Higher Tank Command School named after V. I. Lenin. In 1952, he graduated from the Kazan State Conservatory, the class of composition. In 1951-1956, Bakirov taught at the Kazan College of $\mathrm{Mu}-$ sic. In 1956-1957, he worked as the head of the literary department of the Musa Jalil Tatar Opera and Ballet Theater. In 1958, Bakirov built and opened Music School No. 1 in
Әнвәр Закир улы Бакиров (7 июль 1920, Казан - 10 август 2001, Казан) - татар композиторы, Татарстанның һәм Россиянең атказанган сәнгать эшлеклесе, Татарстанның халык артисты, Г. Тукай исемендәге Дәүләт премиясе лауреаты. Музыкаль белемне ул Казан музыка училищесында ала. 1940 елда хәрби хезмәткә алына. 1942 елны В. И. Ленин исемендәге Ульяновск югары командалык танк училищесын тәмамлый. Бөек Ватан сугышы елларында армия сафларында була. 1946 елда гвардия лейтенанты званиесендә отставкага чыга.

Сугыштан соң ул Казан дәүләт консерваториясендә укуын дәвам итә. 1951-56 елларда Казан музыка училищесында укыта. 1956-57 елларда Муса Жәлил исемендәге Татар дәүләт опера һәм балет театрында әдәби бүлек мөдире булып эшли. 1958
Энвер Закирович Бакиров (7 июля 1920, Казань - 10 августа 2001, Казань) - советский и российский композитор, заслуженный деятель искусств Татарской АССР (1969), РСФСР (1981), лауреат Государственной премии ТАССР имени Габдуллы Тукая (1973), народный артист Республики Татарстан (1993). В 1940 г. окончил Казанское музыкальное училище. В 1940-1946 гг. проходил службу в вооруженных силах, уволился в звании гвардии лейтенанта. В 1942 г. окончил Ульяновское высшее танковое командное училище имени В. И. Ленина. В 1952 г. окончил Казанскую государственную консерваторию по классу композиции. В 1951-1956 гг. преподавал в Казанском музыкальном училище. В 1956-1957 гг. работал заведующим литературной частью Татарского театра оперы и балета имени Мусы Джалиля. В 1958 г. Ба- 
the city of Elabuga, which now bears his name. In 1957-1970, he worked in children's music schools in Kazan and Elabuga. елны Әнвәр Бакиров Алабуга шәһәрендә музыка мәктәбе оештыра. Бүген ул музыка мәктәбе аның исемен йөртә. 1957-70 елларда Казан, Алабуга балалар музыка мәктәпләрендә укыта. киров построил и открыл музыкальную школу № 1 в городе Елабуге, которая в настоящее время носит его имя. В 1957-1970 гг. работал в детских музыкальных школах Казани, Елабуги.
Composer Enver Zakirovich Bakirov was the same age as Tatarstan. He grew up and matured along with his republic, he shared its worries, anxieties, and joys. Therefore, he always felt internally tuned to civic themes and was one of the first to respond to the most important events in the life of his people and his country.

Enver Bakirov was born on July 7, 1920, in Kazan. People used to say: "He was born on the day of Sabantuy - that means he will be a musician!"

The future composer received his first musical impressions in early childhood. The family had a special musical microclimate. His parents played the harmonicas, his sisters, Maryam and Gulsum, played the mandolins, his brother, Khamit Bakirov, was a fairly well-known kurai, kubyz, and clarinet player, later he worked as a soloist in the Philharmonic Society, his younger brothers, Shamil and Nail, were musicians too. Little Enver also participated in the family ensemble.

Having become a well-known composer and the author of many popular musical pieces that everybody liked, E. Bakirov would say that a person's comprehension of folklore "is deeply rooted in the genealogy, the impressions of childhood, coming from the musical microclimate of the environment where the future composer is molded and where he actually creates his works" [Gurarii, p. 21].

From childhood, owing to his family musical environment, Enver Bakirov knew not only Tatar folk music, but also the music for dramatic performances by Salikh Saydashev, an outstanding composer, the founder of Tatar professional music (1900-1954). His most vivid musical impressions of those years were the musical dramas by $S$. Saydashev: "The Hired Man", "Zugur shul" ("A Blue Shawl"), "Kandyr Bue" ("On the Kandra") and others. Even before the release of the play, Saydashev's melodies somehow miraculously reached the audience, and were chanted by the people.

In the future, the work of Salikh Saydashev would have a great influence on his professional development as a musician and composer. Until
1939, Enver Bakirov worked in the orchestra, directed by S. Saydashev, at the Tatar State Academic Theater named after G. Kamal.

In the village of Aldermysh, the Vysokogorsk district, where the family moved in 1924, the rural intellectuals, teachers, and music enthusiasts organized concerts, folk festivals, and staged performances. Young Enver took part in the play "SYngun yoldyzlar" ("The Fading Stars") by Karim Tinchurin, acting as a young shepherd.

Enver had a clear voice and the boy was very fond of singing, first he sang with a kurai accompaniment, then, gradually, he learned to play the two-row accordion. As a schoolboy in a pioneer camp in Shelanga, he first got acquainted with the piano and tried to pick out folk melodies. The composer recalled: "I remember that I could not use an octave, and I was very worried about it, I really wanted to do doubling in the bass. The desire to feel an octave bass was so great that I made such a peculiar device out of wood for using the octave" [Ibid, p. 17].

In 1927, Enver moved from the village to Kazan, where he began his studies at the Mullanur Vakhitov School and participated in the school choir. The radio performance of the choir, where Enver was the soloist, was heard by Ruvim Lvovich Polyakov (1911-1981), the founder of children's music education in the republic, the director of the First Music School. He immediately recognized the boy's great talent, found him, and convinced him to seriously study music. Enver chose a violin [Kompozitory Tatarstana, p. 21]. That moment became a turning point in the life of the future composer - his professional career in the art of music began.

The composer's personality took shape in the 1930s. Bakirov witnessed many significant events. It was a time of creative searches and new achievements: on the one hand, it was the most interesting time; on the other, it was a contradictory period in the history of Tatar music. Nevertheless, that period was extremely important for the entire subsequent cultural process of Kazan [Tatarskii akademicheskii teatr..., p. 17]. The preparation of highly qualified musical personnel was organized 
in those years, which was of great importance for providing a professional base, artistic and creative upsurge of Tatar musical culture [Girshman, Khairullina, Abdullin, p. 139]. New horizons of Tatar music were opening up for the new generation of composers.

In 1934, Enver Bakirov entered the preparatory department of the Kazan Musical College, where he studied violin with Ilyas Aukhadeev (19041968). In 1936, for the first time, a creative group of student composers was created at the school, which, in addition to E. Bakirov, included I. Shamsutdinov, Kh. Valiullin, and others. All of them later became famous professional composers. Under the guidance of a wonderful teacher and composer Georgy Vinogradov (1907-1983), E. Bakirov gained musical theoretical knowledge and learned the basics of composition. In 1940, he successfully graduated from the music school.

From 1940 to 1946, having graduated from the Ulyanovsk Tank School, Enver Bakirov served as an officer in the Soviet Army. But even during the war years, he continued writing music. His songs "Kyz sulme" ("Hello, Girls"), "Appagym" ("My Dear"), "Chuchuk kiyam" ("Collecting Flowers"), "Kemgu suylim?" ("Who Should I Tell?") attract the listener with their simplicity and sincerity.

After demobilization, from 1946 to 1952, he studied at the Kazan State Conservatory, where he improved his composition skills in the class of Albert Lehman (1915-1985), a teacher who made a great contribution to the development of the Tatar school of composition.

As early as during his student years in 1947, Enver Bakirov composed a large number of songs and created his famous sonatina for cello and piano. In the sonatina, the young composer managed to clearly draw a contrast between the extreme fast parts and the middle slow part, in which the music is full of lyricism and poetry. The music of this work with comments in Russian and English was published by the Moscow publishing house [Bakirov, p. 4]. Today as well, a fine sample of his cello music is often performed on the stage.

In the future, numerous instrumental suites and pieces would be written by the composer's quill. The first part of the "Youth Symphony" and a cantata for soloists, chorus, and orchestra became his diploma work.

Composer Enver Bakirov was a true master of the Tatar song. Vocal music, covering different genres, always occupied a special place in his work, he created about four hundred pieces of vocal music - songs, romances, vocal ensembles, du- ets, trios, and works for choir (cantata, oratorio). Many of them have received truly popular recognition.

As a student of a music school, at the age of seventeen, E. Bakirov wrote his first vocal work "Irtənge serenade" ("The Morning Serenade") after the verses of H. Vakhit. The song immediately became popular.

The composer admitted that when composing music, creating songs, he largely relied on the creative principles of Salikh Saydashev, who managed to penetrate the very core of the national spirit. Enver Bakirov gave the greatest preference to the lyric genre "salmak kui" (a moderate melody), which characterizes his songs "Kyr kazlary kitkundu" ("When the Wild Geese Fly Away") after the verses of R. Garay and "Belsun ide" ("I Would Know You ") after S. Hakim's works.

The composer believed that vocal music should demonstrate the relief of musical intonations, the dramatic nature of compositions, and the sincerity of their statement when the lyrics went from heart to heart [Gurarii, p. 21]. Indeed, the response of the audience to the melodies of his songs has always been favourable. The songs "Niemeney kyly kochagy" ("The Warm Mother's Embrace"), "Ytkun idy" ("You Told Me") after the verses of H. Tufan, "Ogur belgun bulsam" ("If I Knew") after the works of Sh. Bikkola, "Mək chəchəge" ("A Poppy Flower") after the works of A. Abdullin and many others became truly folk songs. Enver Bakirov was engaged in creative collaboration with many famous performers - masters of vocal art: N. Dautov, Z. Khismatullina, I. Shakirov and others.

The composer traveled a lot and performed his songs in different regions and cities of the Republic of Tatarstan. At times, listeners were surprised to hear that the songs they thought to be folk ones were written by a professional composer.

Many works are of a patriotic nature. The composer believed that an artist had no right to be indifferent to the life of his country, to the events of his time. A creative person should be emotionally involved in everything going on around him. A specific case, event and experience dictate and determine the genre of the composition. It is necessary to create music not according to a formal order of things, but at the behest of the heart. The degree of sincerity of any work depends on this belief. [Gurarii, p. 20].

Therefore, E. Bakirov dedicated many songs to his native land, the issue of preserving peace on earth. Instantly responding to the events in his country, he composed songs about the conquerors 
of space, the heroes of virgin lands, and oil workers. A good example is the song about Yuri Gagarin, written on the day of the first cosmonaut's flight into space and on the same day performed by I. Shakirov, it was broadcast by Tatar radio. We can also name the songs "Ana Kyry" ("My Mother's Song") after the poem of Sh. Mannur, "Tynychlyk Kyry" ("The Song of the World") after M. Sadri's poem and many others. E. Bakirov has songs that depict his native land, its settlements and villages, separate districts of Tatarstan; in them the composer encourages people to love the beauty of the native land and never forget one's historical roots.

The circle of poets, after whose works Enver Bakirov created his music, is quite diverse, he wrote songs set to the verses from the classics of Tatar poetry (H. Taktash, M. Jalil, etc.), the composer's contemporaries, and even amateur authors. In his choice of lyrics, he was not guided by the rank of the poet. First of all, it was important that there was sound in the text, the plot should be meaningful [Gurarii, p. 20].

KamAZ and its builders is a significant subject of the composer's work. When the foundation of the new city was laid on the banks of the Kama, E. Bakirov, in collaboration with poetess $\mathrm{S}$. Suleimanova, wrote the song "Yashlek Kalasy" ("The City of Youth"), which won third place in the All-Russian competition of patriotic songs. Such monumental works of the composer as "KamAZ Overtures" for a symphony orchestra (1974) and the oratorio "Kama kiңlegendə" ("At the Kama Expanses") (1972), which was positively evaluated by the Ministry of Culture of the RSFSR, are dedicated to the enthusiasm of this grandiose construction.

At KamAZ, Enver Bakirov organized a choir of 800 people. Thanks to the composer's enthusiasm, from 1973, one could hear wonderful choral music at the national holiday of Sabantuy in Naberezhnye Chelny.

From the very beginning of his creative career, the composer wrote music for dramatic performances, he enjoyed working in the genre of musical comedy, which is very popular with the Tatar people. Thus, through the creation of music for these performances and through the search for musical characterizations, he comprehended the essence of the stage action to use it in more complex stage genres, such as opera and ballet.

It was with great success that the performance "Talyan Mogy" ("Talyan's Melody") with E. Bakirov's music ran on the stages of the Tatar Ac- ademic Opera and Ballet Theater named after $\mathrm{Mu}-$ sa Jalil and the Almetyevsk Drama Theater, its first night was on June 29, 1963. In 1970, the three-act musical comedy "Berenche Torch" ("The First Torch'), the libretto by Alla Rustaikis, was staged and dedicated to the 50th anniversary of the TASSR. These performances, depicting the life of drillers, oilmen, and geologists had a successful run at the theaters for many years.

The composer made significant contributions to the enrichment of musical and stage genres. His ballets are a talented interaction of Tatar music national origins and classics.

The premiere of the fairy tale ballet of six scenes "Altyn Tarak" ("The Golden Comb") took place on November 2, 1957. The libretto, written by L. Bordzilovskaya, V. Musatov and G. Salimov, is based on Gabdulla Tukay's "Su anasy" ("The Mermaid"). The creation of the ballet "Altyn Tarak" was preceded by the work on the symphonic poem "Su anasy" ("The Mermaid") (1952).

The performance was produced in the year of the 70th anniversary of the Tatar literature classic. Officially, the production was dedicated to the 40th anniversary of the October Revolution. The music of the performance was full of symphony, integrity, with a touch of lyricism, enabling choreographer L. Bordzilovskaya to solve staging and choreographic problems. The landscape scenery by artist P. Speransky was also remarkable. As noted by reviewers, it was distinguished by poetry and musicality. [Tatar Academic Theater ..., pp. 102-103]. The ballet got a first degree diploma at the AllRussian Festival of Musical Theaters.

The new version of the ballet was staged under the title "Su anasy" ("The Mermaid"), based on G. Tukay's poem of the same name. The choreographer and author of the libretto was Igor Smirnov. The main parts were performed by Galina Kalashnikova, Saniya Khantimirova, Kamil Gainullin, and Nail Sarvarov. The premiere took place on May 7, 1971 [Isanbet, p. 60]. The ballet, striking in its national color and genre characteristics, is one of the best national musical and stage works.

The plot of the ballet "Altyn Tarak" is based on the story of bricklayer Gayfi, his bride Maryam, and Gayna who is trying to destroy their love. She is the wife of Galim-bai and she is in love with Gayfi, (she is also Sulla - a mermaid woman, the owner of a magical golden comb). In the ballet "Su Anasy" the names of the characters have changed. Now it is the young man Almay, his beloved Sarvi, Murza and his beautiful wife - a Mermaid. 
In the new version of the ballet, many episodes that complicated the main storyline have been omitted but the general concept has not been changed. As in the previous edition, the fight of the lovers, Almay and Sarvi, for their happiness develops against the background of folk-routine and magic-fantastic scenes. Musical scenes attract the audience with their expressiveness, melodiousness, a good sense of the choreographic pattern and the unifying leitmotif development [Girshman, p. 291].

A variety of stage situations interweave creating a vivid thematic differentiation, which emphasizes the contrasting opposition of the good and evil, as the forces of love, loyalty, and devotion counteract evil spells, all these equals Enver Bakirov's ballet "Su Anasy" with such masterpieces as "The Fairy's Kiss" by Igor Stravinsky and "Shurale" by Farid Yarullin. Art critics noted the rich melodism, dynamism, and emotionality of the musical language among the main merits of the work [Gurarii, p. 22].

The performance was appreciated by the audience: for a long time the play "Su Anasy" remained one of the most popular Tatar ballets. For a number of years the Musa Jalil Theatre began its tour of the country with this ballet. The performance got a very warm welcome from the audience, the action on the stage was always accompanied by thunderous applause. For the hundredth anniversary of the performance, the author received numerous congratulations from different regions and national republics of our country [Bakirov, p. 5].

This success of the composer's ballet is due to his deep understanding and serious attitude to the genre. According to E. Bakirov, the ballet should begin "with strong drama and its stage value. As you know, there were different periods in the development of ballet. In some of them, a ballet dance became a goal in itself: a dance for the sake of dancing. The ballet became a dance suite. But this dance does not exist to demonstrate dancing technique. Without an inner dramatic movement, dance is dead. Even good music will not save it" [Gurarii, p. 23].

The ballet "Su Anasy" was highly appreciated. In 1973, Enver Bakirov, together with other creators of the performance, was awarded the G. Tukay State Prize of the TASSR. [Tatarskaia entsiklopediia, p. 284].

Unfortunately, at present, the performance is not included in the theatre's repertoire, only sometimes one can hear the composer's ballet suites at symphony concerts.
The opera "Tukay" holds a special place in E. Bakirov's work. For years he created it with all his heart and used all his knowledge to comprehend the poet's personality: "Tukay for the Tatars is someone more than a writer, we are born with Tukay in our hearts. He is like Pushkin for the Russian people. Literally from the cradle, Tukay was with me all my life" [Gurarii, p. 23].

As a composer, E. Bakirov got acquainted with Tukay when he was working on the ballet "The Golden Comb". Then little by little, still unconsciously, he went to the embodiment of the great poet's image on the opera stage. At first, he thought it was unrealistic for Tukay to sing. Although, according to his contemporaries, the poet had a good voice.

That time triggered off the process of a long study of Tukay, his works, and his life. When the composer was firmly established in his idea, he turned to one of the aksakals of Tatar poetry, Akhmet Iskhak. E. Bakirov admitted that it was thanks to this poet that the image of Tukay became clear to him in many ways. In the process of writing the opera, he used authentic folk melodies with Tukay's lyrics, as well as melodies, based on folk lyrics, composed by the poet himself.

In 1982, the opera "Tukay" was positively assessed by the secretariat of the Union of Composers of the RSFSR and was accepted by the Ministry of Culture of the TASSR for staging. Unfortunately, it never appeared on the theater stage. Some fragments, some arias from this opera can be heard only in concert performances. I would like to believe that E. Bakirov's complete work will find its way to the theatre stage.

Along with the composing, E. Bakirov actively conducted educational and pedagogical work. Throughout his life, he taught at the Kazan Music College, children's music schools, contributed articles to periodicals, spoke on radio and television, raised questions about the musical and aesthetic education of the younger generation, and music education at schools.

While studying at the conservatory, he compiled textbooks on music "Жyr həm muzyka dəreslure" ("Lessons of Singing and Music") and "Muzyka Gramotasy" ("Musical Literacy") for elementary Tatar schools; he actually became the first author of musical educational and methodological works in the Tatar language.

The works of Enver Bakirov were published in numerous musical collections, including "Yashlur Kyry” (1952), “Жyrlar" (1955), "Avylym tanary" (1984) and others; there were also collections of 
songs for children, collections of instrumental pieces, and musical arrangements.

Owing to the efforts of the composer, the first music school was opened in Elabuga in 1958. Today, it bears the name of Enver Bakirov.

In Kazan, his name was given to Children's Music School No. 6. The museum of Enver Bakirov has been created here, concerts are organized by students and teachers on the composer's anniversary dates, and competitions of musical performance are held.

Enver Bakirov passed away on August 10, 2001. But his music and songs continue living, people are listening to them and they find a response in our hearts.

For his enormous contributions to the development of Tatar musical art, E. Bakirov was awarded the honorary titles of Honored Art Worker of the TASSR and RSFSR, People's Artist of the Republic of Tatarstan.

\section{References}

Girshman, Ia. M., Khairullina, Z. Sh., Abdullin, A. Kh. (2018). Ocherki po istorii tatarskoi muzyki [Essays on the History of Tatar Music]. Sost. A. A. Abdullina. 376p., 4 1. il. Kazan', IYALI im. G. Ibragimova (seriia "Iz kollektsii, "Miraskhanə”'). (In Russian)

Gurarii, S. I. (1984). Dialogi o tatarskoi muzyke [Dialogues about Tatar Music]. 154 p. Kazan', Tatarskoie knizhnoie izdatel'stvo. (In Russian)

Isanbet, Iu. N. (2003). Slovar' muzykal'nostsenicheskikh proizvedenii tatarskikh kompozitorov, postavlennykh na kazanskoi stsene [Dictionary of Musical and Stage Works of Tatar Composers on the Kazan Stage]. 158 p. Kazan', Magarif. (In Russian)

Kompozitory Tatarstana (2009) [Tatar Composers]. 260 p. Moscow, Kompozitor. (In Russian)

Tatarskaia entsiklopediia (2002) [Tatar Encyclopedia]. Gl. red. M. Kh. Khasanov; otv. red. G. S. Sabirzianov. T. 1: A-V. Pp. 284-285. Kazan', Institut tatarskoi entsiklopedii. (In Russian)

Bakirov, Ә. (1979). Məkhəbbətem [My Love]. Keresh syz Z. Khoirullina. 84 p. Kazan, Tatarstan kitap nəshriiaty. (In Tatar)

Tatarskii akademicheskii teatr opery $i$ baleta imeni Musy Dzhalilia (1994) [Musa Jalil Tatar Academic Opera and Ballet Theater]. Pod obshch. Red. G. M. Kantora. 145 p. Kazan', Kazanskaia gosudarstvennaia konservatoriia. (In Russian)

\title{
МУЗЫКАНТ ПО ВЕЛЕНИЮ СЕРДЩА (К 100-ЛЕТИЮ ИЗВЕСТНОГО ТАТАРСКОГО КОМПОЗИТОРА ЭНВЕРА БАКИРОВА)
}

\author{
Неля Хабибулловна Нургаянова, \\ Казанский федеральный университет, \\ Россия, 420008, г. Казань, ул. Кремлевская, д. 18, \\ Институт языка, литературы и искусства им. Г. Ибрагимова АН РТ, \\ Россия, 420111, г. Казань, ул. К. Маркса, д. 12, \\ naila-n@mail.ru.
}

Композитор Энвер Закирович Бакиров - ровесник Татарстана. Вместе с ним он рос, мужал, делил его заботы, тревоги и радости. Поэтому всегда чувствовал себя внутренне мобилизованным на гражданскую тематику, одним из первых откликался на самые важные события в жизни своего народа, своей страны.

Энвер Бакиров родился 7 июля 1920 года в Казани. Про него говорили: «Он родился в день Сабантуя - значит, будет музыкантом!»

Первые музыкальные впечатления будущий композитор получил в раннем детстве. В семье царил особый музыкальный микроклимат. Родители играли на гармониках, сестры Марьям и Гульсум - на мандолинах, брат, Хамит Бакиров, был довольно известным исполнителем на курае, кубызе, кларнете, впоследствии работал солистом филармонии, младшие братья Шамиль и Наиль, тоже были музыкантами. Маленький Энвер также участвовал в семейном ансамбле.

Став уже известным композитором, автором множества популярных и любимых в народе музыкальных произведений, Э. Бакиров скажет, что постижение человеком фольклора идет «от явлений более почвенных, корневых, уходящих своими истоками в родословную, к впечатлениям детства, в музыкальный микроклимат среды, где формируется будущий композитор и где он, собственно, творит свои произведения» [Гурарий, с. 21].

Благодаря семейному музыкальному окружению, Энвер Бакиров с детства знал не только татарскую народную музыку, но и музыку к 
драматическим спектаклям выдающегося композитора, основоположника татарской профессиональной музыки Салиха Сайдашева (19001954). Музыкальные драмы С. Сайдашева «Наемщик», «Зәңгәр шәл» («Голубая шаль»), «Кандыр буе» («На Кандре») и др. - ярчайшие музыкальные впечатления тех лет. Еще до выхода спектакля сайдашевские мелодии какимто чудом проникали к слушателям, начинали распеваться в народе.

В дальнейшем творчество Салиха Сайдашева окажет большое влияние на его профессиональное становление как музыканта и композитора. Вплоть до 1939 года Энвер Бакиров будет работать в оркестре под управлением С. Сайдашева в Татарском государственном академическом театре им. Г. Камала.

В деревне Альдермыш Высокогорского района, куда семья переехала в 1924 году, силами сельской интеллигенции, учителями, музыкальными энтузиастами организовывались концерты, народные праздники, ставились спектакли. В постановке пьесы Карима Тинчурина «Сүнгән йолдызлар» («Угасшие звезды») принял участие и юный Энвер, выступив в роли пастушка.

У Энвера был звонкий голос, мальчик очень любил петь, сначала в сопровождении курая, затем постепенно сам научился играть на двухрядной гармошке. Уже будучи школьником, в пионерском лагере в Шеланге, он впервые познакомился с фортепиано, пробовал подбирать народные мелодии. Композитор вспоминал: «Помню, что октаву брать не мог, и очень переживал из-за этого, мне ужасно хотелось делать удвоение в басах. Желание ощутить октавный бас было так велико, что я смастерил такое своеобразное приспособление из дерева для взятия октавы» [Там же, с. 17].

В 1927 году Энвер переезжает из деревни в Казань, где начинает учиться в школе имени Мулланура Вахитова, участвует в школьном хоре. Выступление хора по радио, где Энвер солировал, услышал Рувим Львович Поляков (1911-1981) - основоположник детского музыкального образования в республике, директор Первой музыкальной школы. Он сразу же распознал огромный талант мальчика, отыскал его и убедил в необходимости серьезно обучаться музыке. Энвер выбирает скрипку [Композиторы Татарстана, с. 21]. Этот момент стал определяющим в жизни будущего композитора началась его профессиональная жизнь в музыкальном искусстве.
Становление личности композитора пришлось на тридцатые годы XX века. Бакиров был свидетелем многих значительных событий. Это было время творческих исканий, новых свершений: с одной стороны, интереснейший, с другой - противоречивый период в истории татарской музыки. Тем не менее этот период был чрезвычайно важным для всего последующего культурного процесса Казани [Татарский академический театр..., с. 17]. Неоценимое значение для обеспечения профессиональной базы, художественного и творческого подъема татарской музыкальной культуры имела организованная в эти годы подготовка высококвалифицированных музыкальных кадров [Гиршман, Хайруллина, Абдуллин, с. 139]. Перед новым поколением композиторов открывались новые горизонты татарской музыки.

В 1934 году Энвер Бакиров поступает на подготовительное отделение Казанского музыкального училища, где по классу скрипки обучается у Ильяса Ваккасовича Аухадеева (19041968). В 1936 г. в училище впервые создается творческая группа студентов-композиторов, в состав которой, помимо Э. Бакирова, вошли И. Шамсутдинов, Х. Валиуллин и др. Все они в дальнейшем стали известными профессиональными композиторами. Под руководством замечательного педагога и композитора Георгия Васильевича Виноградова (1907-1983) Э. Бакиров получает музыкально-теоретические знания, постигает основы композиции. В 1940 году он успешно оканчивает музыкальное училище.

С 1940 по 1946 г. Энвер Бакиров, закончив Ульяновское танковое училище, служит офицером Советской Армии. Но и в военные годы он не прекращает писать музыку. Песни «Кыз сәләме» («Привет девушки»), «Аппагым» («Моя милая»), «Чәчәк жыям» («Собираю цветы»), «Кемгә сөйлим?» («Кому рассказать?») привлекают своей простотой и искренностью.

После демобилизации с 1946 по 1952 г. обучается в Казанской государственной консерватории, где совершенствуется по композиции в классе Альберта Семеновича Лемана (1915-1985) - педагога, внесшего большой вклад в развитие татарской композиторской школы.

Еще в студенческие годы в 1947 г. Энвер Бакиров сочиняет большое количество песен, пишет знаменитую сонатину для виолончели и фортепиано. В сонатине молодому композитору удается ярко провести контраст между крайними быстрыми частями и средней медленной 
частью, музыка которой одухотворена лиризмом и поэтичностью. Ноты этого произведения с комментариями на русском и английском языках опубликованы Московским издательством [Бакиров, с. 4]. И в настоящее время прекрасный образец виолончельной музыки часто звучит со сцены.

В дальнейшем из-под пера композитора выйдут многочисленные инструментальные сюиты и пьесы. Дипломной работой стали 1 часть «Молодежной симфонии» и кантата для солистов, хора и оркестра.

Композитор Энвер Бакиров - истинный мастер татарской песни. Вокальная музыка, охватывающая разные жанры, всегда занимала особое место в его творчестве, им создано около четырехсот образцов вокальной музыки песен, романсов, вокальных ансамблей, дуэтов, трио, сочинений для хора (кантата, оратория). Многие получили истинно народное признание.

Первое вокальное произведение «Иртәнге серенада» («Утренняя серенада») на стихи Х. Вахита Э. Бакиров написал в семнадцатилетнем возрасте, будучи студентом музыкального училища. Песня сразу же стала популярной.

Композитор признавался, что, сочиняя произведения, создавая песни, во многом опирался на творческие принципы Салиха Сайдашева, сумевшего проникнуть в самую сердцевину народного духа. Наибольшее предпочтение Энвер Бакиров отдавал лирическому жанру «салмак көй» (умеренный напев), что отразилось в таких песнях, как «Кыр казлары киткәндә» («Когда улетают дикие гуси») на стихи Р. Гарая, «Белсән иде» («Знала бы ты») на слова С. Хакима.

Композитор считал, что в вокальной музыке должны проявляться рельефность музыкальных интонаций, драматургичность композиций, искренность высказывания, когда пишется от сердца - до сердца [Гурарий, с. 21]. Действительно, мелодии его песен всегда находили душевный отклик у слушателей. Поистине народными стали песни «Әниемнең жылы кочагы» («Теплое объятие матери»), «Әйткән идең» («Ты говорила мне») на стихи Х. Туфана, «Әгәр белгән булсам» («Если б я знал») на слова Ш. Биккола, «Мәк чәчәге» («Цветок мака») на слова А. Абдуллина и многие другие. Творческое содружество связывало Энвера Бакирова со многими известными исполнителями - мастерами вокального искусства, среди которых $\mathrm{H}$. Даутов, 3. Хисматуллина, И. Шакиров и др.
Композитор много ездил с выступлениями в разные районы и города Республики Татарстан. Порой слушатели очень удивлялись, узнавая, что песни, которые они считали народными, написаны профессиональным композитором.

Немало произведений носит патриотический характер. Композитор считал, что «художник не имеет права не откликаться на жизнь своей страны, на события своего времени. Творческий человек все пропускает сквозь себя. Конкретный случай, событие, переживание диктуют, определяют жанр сочинения. Нужно писать не по формальному заказу, а по велению сердца. От этого зависит степень искренности любого произведения» [Гурарий, с. 20]. Поэтому множество песен Э. Бакиров посвятил родному краю, проблеме сохранения мира на земле, писал песни о покорителях космоса, героях-целинниках, нефтяниках, моментально откликаясь на события, происходящие в стране. Показательный пример - песня о Ю. Гагарине, написанная в день полета первого космонавта в космос и в тот же день переданная татарским радио в исполнении И. Шакирова. Также можно назвать песни «Ана жыры» («Песня матери») на слова Ш. Маннура, «Тынычлык жыры» («Песня мира») на слова М. Садри и многие другие. У Э. Бакирова есть песни, в которых показаны картины родного края, села, деревни, отдельные районы Татарстана, в них композитор призывает любить красоту родной природы, не забывать свои исторические корни.

Круг поэтов, к творчеству которых обращался Энвер Бакиров, довольно разнообразен, он писал песни и на стихи классиков татарской поэзии (X. Такташ, М. Джалиль и др.), и современников композитора, и даже самодеятельных авторов. В выборе текстов он ориентировался не на ранг поэта. Прежде всего было важно, чтобы звучал текст, чтобы он был сюжетно содержательным [Гурарий, с. 20].

Яркой полосой в творчестве композитора проходит тема КамАза и его строителей. Когда на берегах Камы начинает расти новый город, Э. Бакиров в соавторстве с поэтессой С. Сулеймановой пишет песню «Яшьлек каласы» («Город молодости»), получившую третье место на Всероссийском конкурсе патриотических песен. Энтузиазм грандиозной стройки отражен в таких монументальных произведениях композитора, как «КамАЗ увертюрасы» для симфонического оркестра (увертюра «КамАЗ») $(1974$ г.) и оратория «Кама киңлегендә» («На 
Камских просторах») (1972 г.), положительно оцененная Министерством культуры РСФСР.

На КамАЗе Энвер Закирович организовал хор, состоящий из 800 человек. Благодаря энтузиазму композитора, с 1973 года в Набережных Челнах на национальном празднике Сабантуй можно было услышать прекрасное звучание хоровой музыки.

С самого начала творческой деятельности композитор пишет музыку к драматическим спектаклям, с удовольствием работает в весьма популярном у татарского народа жанре музыкальной комедии. Таким образом, через создание музыки к спектаклям, поиск музыкальных характеристик героев происходит постижение сущности сценического действия для работы в более сложных сценических жанрах, таких как опера и балет.

$\mathrm{C}$ огромным успехом на сценах Татарского академического театра оперы и балета имени Мусы Джалиля и Альметьевского драматического театра шел спектакль с музыкой Э. Бакирова «Тальян моңы» («Мелодия тальянки»), премьера которого состоялась 29 июня 1963 г. В 1970 году к 50-летнему юбилею ТАССР ставится музыкальная комедия в трех действиях «Беренче факел» («Первый факел») на либретто Аллы Рустайкис. Эти спектакли, посвященные жизни буровиков, нефтяников, геологов, в течение многих лет не сходили со сцен театров.

Значительна заслуга композитора в обогащении музыкально-сценических жанров. В его балетах талантливо взаимодействуют национальные истоки татарской музыки и классика.

2 ноября 1957 года, состоялась премьера балета-сказки в шести картинах «Алтын тарак» («Золотой гребень»). В основу либретто, написанного Л. А. Бордзиловской, В. И. Мусатовым и Г. Ф. Салимовым, легло произведение Габдуллы Тукая «Су анасы». Созданию балета «Алтын тарак» предшествовала работа над симфонической поэмой «Су анасы» («Водяная») (1952 г.).

Спектакль поставлен в год 70-летия классика татарской литературы. Официально постановка была посвящена 40-летию Октября. Музыка спектакля полна симфонизма, цельная, с налетом лирики, помогала балетмейстеру Бордзиловской в решении постановочных и хореографических задач. Замечательны были и пейзажные декорации художника П. Сперанского. Как отмечали рецензенты, они отличались поэтичностью и музыкальностью. [Татарский академический театр..., с. 102-103]. На Всерос- сийском фестивале музыкальных театральных коллективов балет получил диплом первой степени.

В новой редакции балет был поставлен под названием «Су анасы» («Водяная»), по мотивам одноименной поэмы Г. Тукая. Балетмейстер и автор либретто - Игорь Смирнов. Главные партии исполнили Галина Калашникова, Сания Хантимирова, Камиль Гайнуллин, Наиль Сарваров. Премьера состоялась 7 мая 1971 года [Исанбет, с. 60]. Яркий по национальному колориту и жанровой характеристике балет вошел в число лучших национальных музыкальносценических произведений.

Сюжетную основу балета «Алтын тарак» составляет история каменщика Гайфи и его невесты Марьям, любовь которых стремится разрушить влюбившаяся в Гайфи Гайна - жена Галим-бая (она же Сулла - женщина-русалка, обладательница волшебного золотого гребня). В балете «Су анасы» изменились имена героев. Теперь - это юноша Алмай, его возлюбленная Сарви, Мурза и его красавица жена - она же Водяная.

В новом варианте балета сняты многие эпизоды, осложнявшие главную сюжетную линию, но общая концепция не претерпела изменений. Как и в прежней редакции, борьба влюбленных Алмая и Сарви за свое счастье происходит на фоне народно-бытовых и волшебно-фантастических сцен. Музыкальные номера привлекают своей выразительностью, мелодичностью, хорошим чувством хореографического рисунка и скрепленным лейтмотивным развитием [Гиршман, с. 291].

Переплетение разнообразных сценических ситуаций, позволяющее создать яркую тематическую дифференциацию, подчеркивает контрастное противопоставление противоборствующих сил добра и зла, когда силы любви, верности и преданности противодействуют злым чарам, что приближает балет «Су анасы» Энвера Бакирова к таким шедеврам, как «Поцелуй Феи» Игоря Стравинского, «Шурале» Фарида Яруллина. Критики среди главных достоинств произведения отмечали насыщенный мелодизм, динамичность, эмоциональность музыкального языка [Гурарий, с. 22].

Постановка была оценена и слушателями: спектакль «Су анасы» долгое время» оставался одним из самых посещаемых татарских балетов. В течение ряда лет ТАТОиБ имени Мусы Джалиля начинал гастроли по стране с этого балета. Зрители тепло принимали спектакль, 
действие на сцене всегда сопровождалось бурными аплодисментами. На сотый юбилейный показ спектакля автором были получены многочисленные поздравления из разных регионов и национальных республик нашей страны [Бакиров, с. 5].

Такой успех балетного творчества композитора кроется в его глубоком понимании особенностей жанра. По словам Э. Бакирова, балет должен начинаться «с крепкой драматургии, его сценичности. Были, как известно, разные периоды в развитии балета. В некоторых из них танец в балете превращается в самоцель. Танец ради танца. Балет превращался в танцевальную сюиту. Но этот танец существует не для демонстрации техники. Без внутреннего драматургического движения танец мертв. Его не спасет даже добротная музыка» [Гурарий, с. 23].

Балет «Су анасы» получил высокую оценку - Энвер Бакиров вместе с другими создателями спектакля в 1973 году был удостоен Государственной премии ТАССР им. Г. Тукая [Татарская энциклопедия, с. 284].

К сожалению, в настоящее время спектакль отсутствует в репертуаре театра, лишь иногда в симфонических концертах можно услышать балетные сюиты композитора.

Особое место в творчестве Э. Бакирова занимает опера «Тукай», к которой он шел многие годы, вложив всю душу, знания в понимание личности поэта: «Тукай для татар нечто большее, чем писатель, мы рождаемся с Тукаем в сердце. Это как для русского народа Пушкин. Буквально с колыбели Тукай был со мной всю жизнь» [Гурарий, с. 23].

Первая встреча как композитора с творчеством Тукая была в работе над балетом «Золотой гребень». Тогда-то исподволь, еще неосознанно он идет к воплощению образа великого поэта на оперной сцене. Сначала ему казалось нереальным, чтобы Тукай пел, хотя, по свидетельству современников, поэт обладал неплохим голосом.

С этого времени начался процесс длительного изучения Тукая, его сочинений, его жизни. Когда композитор утвердился в своем замысле, то обратился к одному из аксакалов татарской поэзии Ахмету Исхаку. Э. Бакиров признавал, что образ Тукая-поэта во многом прояснился для него именно благодаря этому поэту. В процессе написания оперы были использованы подлинные народные мелодии на слова Тукая, а также мелодии, сочиненные самим поэтом на народные слова.
В 1982 году опера «Тукай» получила положительную оценку секретариата Союза композиторов РСФСР и была принята Министерством культуры ТАССР к постановке. К сожалению, на сцене театра она так и не была поставлена. Некоторые фрагменты, отдельные арии из этой оперы звучат только в концертном исполнении. Хочется верить, что полный труд Э. Бакирова еще найдет свое сценическое воплощение.

Наряду с композиторской деятельностью, в течение всей жизни Э. Бакиров активно вел просветительскую и педагогическую работу, преподавал в Казанском музыкальном училище, детских музыкальных школах, много выступал в периодической печати, на радио и телевидении, поднимал вопросы о музыкальноэстетическом воспитании молодого поколения, музыкальном образовании в школе.

Еще во время учебы в консерватории он составляет пособия по музыке для начальных татарских школ «Жыр һәм музыка дәресләре» («Уроки пения и музыка»), «Музыка грамотасы» («Музыкальная грамота»), фактически становится первым автором музыкальных учебнометодических работ на татарском языке.

Произведения Энвера Бакирова опубликованы в многочисленных нотных сборниках, среди которых «Яшьләр жыры» (1952), «Жырлар» (1955), «Әниемнең жылы кочагы» (1960), «Мәк чәчәге» (1969), «Мәхәббәтем» (1979), «Авылым таңнары» (1984) и др.; изданы сборники песен для детей, сборники инструментальных пьес и переложений.

Благодаря усилиям композитора в 1958 году в Елабуге открывается первая музыкальная школа. Сегодня она носит имя Энвера Бакирова.

В Казани его имя также присвоено детской музыкальной школе № 6. Здесь создан музей Энвера Бакирова, к юбилейным датам композитора силами учащихся и педагогов организуются концерты, проводятся исполнительские конкурсы.

Энвера Бакирова не стало 10 августа 2001 года. Но его музыка и песни продолжают жить, звучать и находить отклик в сердцах людей.

За огромный вклад в развитие татарского музыкального искусства Э. Бакиров удостоен почетных званий заслуженного деятеля искусств ТАССР и РСФСР, народного артиста Республики Татарстан. 


\section{Литература}

Гиршман Я. М., Хайруллина 3. Ш., Абдуллин А. $X$. Очерки по истории татарской музыки / сост. А. А. Абдуллина. Казань: ИЯЛИ им. Г. Ибрагимова, 2018. 376 с.: 4 л. ил. (серия «Из коллекции „Мирасханә“»).

Гурарий С. И. Диалоги о татарской музыке. Казань: Татарское книжное издательство, 1984. 154 с.

Исанбет Ю. H. Словарь музыкальносценических произведений татарских композиторов, поставленных на казанской сцене. Казань: Магариф, 2003. $158 \mathrm{c}$.

Композиторы Татарстана. Москва: Композитор, 2009. $260 \mathrm{c}$.
Татарская энциклопедия / гл. ред. М. Х. Хасанов; отв. ред. Г. С. Сабирзянов. Казань: Институт татарской энциклопедии, 2002. Т. 1: А-В. С. 284285.

Бакиров Ә. Мәхәббәтем / кереш сүз 3. Хәйруллина. Казан: Татарстан китап нәшрияты, 1979. 84 б. (на тат. языке).

Татарский академический театр оперы и балета имени Мусы Джалиля / Под общ. Ред. Г.М. Кантора. Казань: Казанская государственная консерватория, 1994. 145 c. 